Revue bibliographique pour le domaine irano-aryen

\title{
Samra Azarnouche. Appendice au point IV. « Les Gaures zoroastriens » par Jean-Pierre Mahé, «Gabriel de Chinon, missionnaire dans l'Empire safavide (1647-1668)»
}

\section{Florence Somer}

\section{(2) OpenEdition \\ Journals}

Édition électronique

URL : http://journals.openedition.org/abstractairanica/50811

DOI : 10.4000/abstractairanica.50811

ISBN : 1961-960X

ISSN : 1961-960X

Éditeur :

CNRS (UMR 7528 Mondes iraniens et indiens), Éditions de l'IFRI

\section{Référence électronique}

Florence Somer, « Samra Azarnouche. Appendice au point IV. « Les Gaures zoroastriens » par JeanPierre Mahé, " Gabriel de Chinon, missionnaire dans l'Empire safavide (1647-1668) » », Abstracta Iranica [En ligne], Volume 40-41 | 2019, document 5, mis en ligne le 30 décembre 2019, consulté le 19 avril 2021. URL : http://journals.openedition.org/abstractairanica/50811 ; DOI : https://doi.org/ 10.4000/abstractairanica.50811

Ce document a été généré automatiquement le 19 avril 2021.

Tous droits réservés 


\title{
Samra Azarnouche. Appendice au point IV. "Les Gaures zoroastriens » par Jean-Pierre Mahé, « Gabriel de Chinon, missionnaire dans l'Empire safavide (1647-1668)»
}

\author{
Florence Somer
}

\section{RÉFÉRENCE}

Samra Azarnouche. Appendice au point IV. « Les Gaures zoroastriens » par Jean-Pierre Mahé, « Gabriel de Chinon, missionnaire dans l'Empire safavide (1647-1668) », Journal des Savants, 2, 2018, p. 412-419

Complément à un article détaillant le voyage du Père franciscain Gabriel de Chinon (1610-1668) dans l'Iran de Shah Abbas II, et les débuts du règne de Suleyman Ier, cet article complète et réévalue, en les replaçant dans leur contexte historique, philologique et religieux, les informations apportées par le Père catholique sur le zoroastrisme dans son ouvrage Relations nouvelles du Levant, ou Traités de la religion, du gouvernement \& des coutumes des Perses, des Arméniens \& des Gaures. Interrogeant les zoroastriens contemporains sur les origines de leurs coutumes et la place de leur religion au sein de la descendance abrahamique, le missionnaire chrétien intègre artificiellement dans une mythologie biblique les origines du zoroastrisme ainsi que certaines coutumes propres à cette communauté religieuse. Il témoigne également de pratiques particulières comme l'hécatombe des xrafstar (vermine) ou les rites funéraires. 


\section{AUTEURS}

\section{FLORENCE SOMER}

Doctorante EPHE, Mondes iranien et indien, Paris 